\title{
Habitat complexity and community composition: relationships between different ecosystem engineers and the associated macroinvertebrate assemblages
}

\author{
María Cruz Sueiro • Alejandro Bortolus • \\ Evangelina Schwindt
}

Received: 19 April 2010/Revised: 10 November 2010/ Accepted: 11 November 2010/Published online: 27 November 2010 (C) Springer-Verlag and AWI 2010

\begin{abstract}
Several species of ecosystem engineers inhabiting coastal environments have been reported structuring different kinds of communities. The magnitude of this influence often depends on the habitat complexity introduced by the engineers. It is commonly accepted that an increase in habitat complexity will result in an increase in diversity and/or abundance in the associated fauna. The rocky salt marshes along the coast of Patagonia are dominated by cordgrasses, mussels, and barnacles forming a mosaic of engineered habitats with different complexity. This system allows us to address the following questions: how different is a macroinvertebrate assemblage when dominated by different ecosystem engineers? And, is there a positive relationship between increasing habitat complexity and the species richness, diversity and total density of the assemblages? To address these questions, we compared the three ecological scenarios with decreasing habitat complexity: cordgrass-mussel, mussel, and barnacle-engineered habitats. We found a total of 22 taxa mostly crustaceans and polychaetes common to all scenarios. The three engineered habitats showed different macroinvertebrate assemblages, mainly due to differences in individual abundances of some taxa. The cryptogenic amphipod
\end{abstract}

Communicated by Luis Gimenez.

M. C. Sueiro $(\square) \cdot$ A. Bortolus · E. Schwindt Grupo de Ecología en Ambientes Costeros,

CENPAT-CONICET, U9120ACD Puerto Madryn,

Chubut, Argentina

e-mail: cruz@cenpat.edu.ar

M. C. Sueiro

Facultad de Ciencias Exactas y Naturales,

Universidad de Buenos Aires, Ciudad Universitaria,

Intendente Güiraldes 2160, C1428EGA Buenos Aires, Argentina
Orchestia gammarella was found strictly associated with the cordgrass-mussel habitat. Species richness and diversity were positively related with habitat complexity while total density showed the opposite trend. Our study suggests that species vary their relative distribution and abundances in response to different habitat complexity. Nevertheless, the direction (i.e., neutral, positive or negative) and intensity of the community's response seem to depend on the physiological requirements of the different species and their efficiency to readjust their local spatial distribution in the short term.

Keywords Ecosystem engineers - Habitat complexity · Macroinvertebrate assemblage

\section{Introduction}

The concept of ecosystem engineering is currently well recognized among ecologists worldwide and refers to the physical modification, maintenance, or creation of habitat by organisms (Jones et al. 1997). The engineer organisms can change the physical structure, complexity, and heterogeneity of the environment having a marked influence on the associated communities (Jones et al. 1994, 1997; Crooks 2002). Of these environmental features, habitat complexity encompasses the absolute abundance of individual structural components of the habitat and has long been considered one of the determinants of biological diversity (McCoy and Bell 1991). Thus, the magnitude of the influence of different engineer organisms often depends on the habitat complexity introduced by them, and the way this habitat complexity modulates the environmental forces and/or biological processes that shape the associated community, in terms of their species richness, diversity and 
density (Gutiérrez and Iribarne 2004; Hastings et al. 2007; Bouma et al. 2009).

Several species of ecosystem engineers inhabiting coastal environments have been reported structuring different sorts of communities by increasing habitat complexity as a consequence of providing living space with different structural components and/or by generating quantitative changes in the amount of living space. For instance, mussel beds, reef-building organisms and many species of plants form highly compact and imbricate structures above and below ground in soft bottom environments, increasing the availability of food, substratum for larvae settlement and supplying new refugia from predators and physical unfavorable conditions (Schwindt et al. 2001; Callaway 2006; Levin et al. 2006; Commito et al. 2008; Jackson et al. 2008; Buschbaum et al. 2009; Maggi et al. 2009).

It is widely accepted that an increase in habitat complexity will increase the diversity and/or abundance of the associated fauna (Crooks 2002; Bouma et al. 2009). The underlying hypothesis is that a greater amount of structure will provide more resources, habitats and niches (Connor and McCoy 2001). Many studies have been designed to evaluate the effect of a given ecosystem engineer on different faunal assemblages, and they usually compare presence versus absence of the ecosystem engineer (e.g., Castilla et al. 2004; Borthagaray and Carranza 2007). However, less effort has been directed to evaluate the effect of different engineers on a single faunal assemblage. Moreover, the papers compiled in Table 1 show that the direction of the effect exerted by ecosystem engineers with different habitat complexities may be hard to predict. In fact, the analysis and study of this ecological problem is strongly scale-dependent, because the notion and magnitude of structural complexity assigned to a given habitat will vary depending on the species under consideration. Indeed, meio- and microfaunal organisms such as nematodes, ostracodes, and ciliates are not likely to even respond to the same kind of differences in complexity than megafaunal organisms such as the sea lions, or even smaller organisms like cormorants and penguins, do. Nevertheless, since the study of large spectrum of habitat complexity (i.e., including macro and microscopic scales) is virtually impossible, scientists often advocated for partitioning their study systems.

The rocky salt marshes of Patagonia were recently described as an environmental intersection between rocky intertidal and salt marsh (Bortolus et al. 2009). In this environment, three well-known ecosystem engineers can be found coexisting and characterizing the intertidal: cordgrass, mussels, and non-native barnacle. Different species of cordgrass, mussels, and barnacles have been reported to alter light, temperature, wave action, sedimentation, and food availability, which in turns have influenced with the abundance and distribution of invertebrate fauna (e.g. cordgrass: Capehart and Hackney 1989; Netto and Lana 1999; Hedge and Kriwokwen 2000; Bortolus et al. 2002; mussels: Thiel and Ullrich 2002; Adami et al. 2004; Prado and Castilla 2006; barnacles: Bros 1980; Barnes 2000; Harley 2006). However, the differences on the amount of structural components of these ecosystem engineers species supply three contrasting natural scenarios with increasing habitat complexity (from high to low: cordgrass-mussel-engineered, musselengineered, and barnacle-engineered habitats) that allow us to address the following questions: How different is a macroinvertebrate assemblage when dominated by different ecosystem engineers? And, is there a positive relationship between increasing habitat complexity and the species richness, density and total density of the assemblages?

\section{Materials and methods}

\section{Study system}

The Patagonian rocky salt marshes develop on top of wavecut platforms of sedimentary rock and are dominated by a dwarf ecotype of the austral cordgrass Spartina densiflora Brong. (the Patagonian ecotype; see Bortolus 2006; Fortuné et al. 2008; Bortolus et al. 2009) covering about $40 \%$ of the substratum. The unvegetated areas are dominated either by a dense bed of the native mussels Perumytilus purpuratus (Lamarck 1819) and Brachidontes rodriguezii (d'Orbigny 1846) or by the only intertidal species of barnacle in this region, the non-native Balanus glandula Darwin 1854 while the occurrence of bare rock is virtually nil in this area. In this system, the cordgrasses have a very compact and thick mat of roots and rhizomes (mean biomass of $22 \pm 10 \mathrm{~g} 100 \mathrm{~cm}^{-2}$; Sueiro, unpublished data), which in turn is covered by a dense mat of mussels (mean density of $133 \pm 51$ ind $100 \mathrm{~cm}^{-2}$; Sueiro, unpublished data) underneath a homogeneous $30 \mathrm{~cm}$ height canopy (mean biomass of $4 \pm 2 \mathrm{~g} 100 \mathrm{~cm}^{-2}$; Sueiro, unpublished data) (Bortolus et al. 2009; Fig. 1). As a result, these patches provide the highest amount of available space and microhabitats with their different structural components, thus generating the more complex habitat. The next lower level of habitat complexity is presented by the mussels, which are also found in the rocky shores devoid of cordgrass. In this case even though the mussels are the only structural component, they form highly dense and multilayer beds, providing an intermediate amount of available space and microhabitats (mean density $160 \pm 42$ ind $100 \mathrm{~cm}^{-2}$; Sueiro, unpublished data, Fig 1) (Adami 


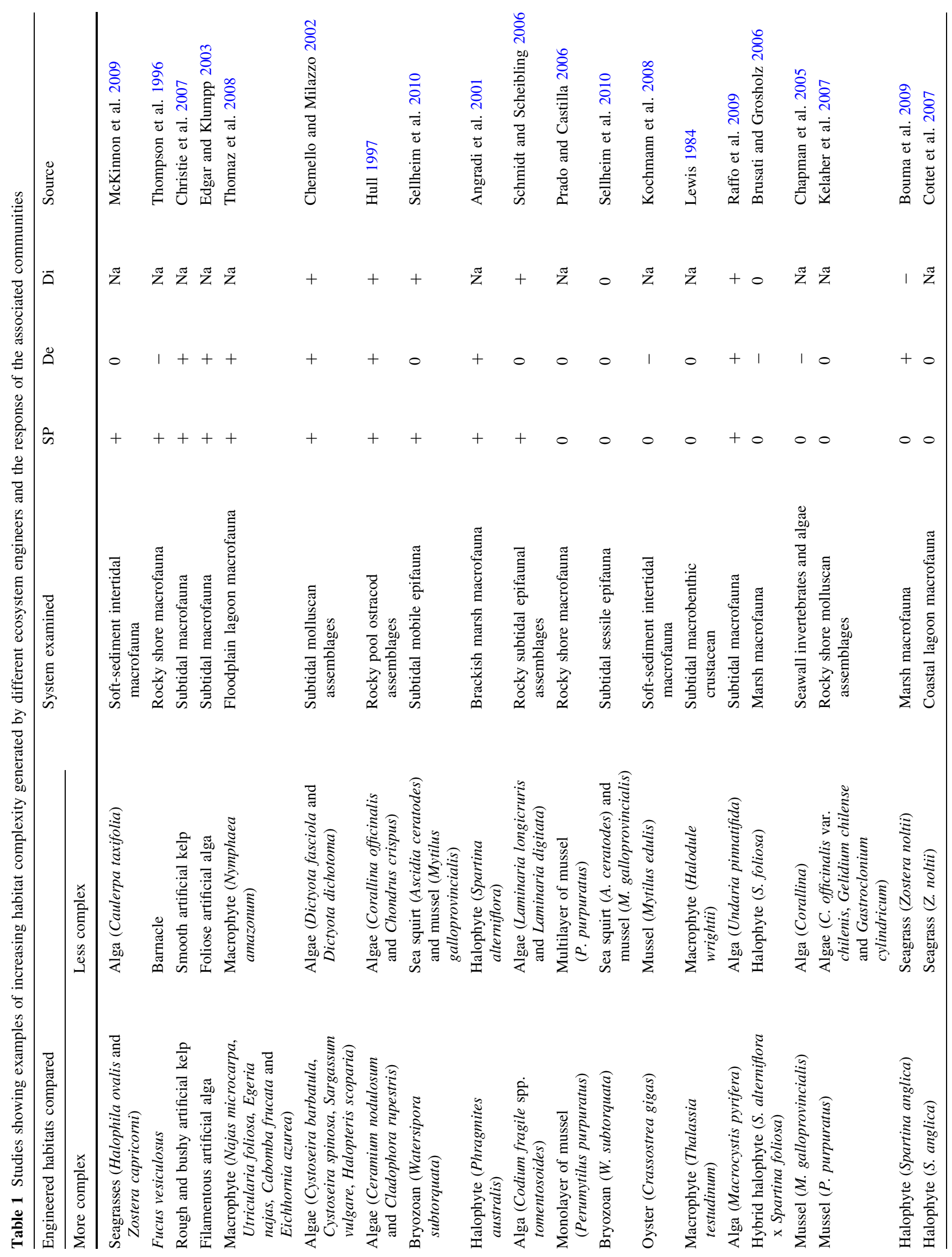


et al. 2004; Bertness et al. 2006; Prado and Castilla 2006). Finally, the simplest habitat complexity level in the rocky marshes is generated by carpets (mono-layers less than $1 \mathrm{~cm}$ height) formed by barnacles on the rocky bottom (mean density $146 \pm 59$ ind $100 \mathrm{~cm}^{-2}$; Sueiro, unpublished data) without mussels or cordgrasses (Schwindt 2007; Savoya and Schwindt 2010; Fig. 1). The non-native Balanus glandula, the only structural component in these patches, is strongly cemented to the substratum and prevents the formation of the sub-superficial community of invertebrates often found underneath the mussel beds that are attached to the substratum with abundant byssal threads. The existence of different combinations of these same habitats is possible, but not pertinent within the context of this study. Field surveys were conducted in rocky salt marshes distributed along the shore of the Nuevo Gulf in the Argentinean Patagonia $\left(42^{\circ} 36^{\prime} \mathrm{S}, 64^{\circ} 49^{\prime} \mathrm{W}\right.$; Fig. 1). The climate is mostly arid with low precipitations $\left(<200 \mathrm{~mm} \mathrm{year}^{-1}\right)$, annual temperatures ranging from $39^{\circ} \mathrm{C}$ to $-7.5^{\circ} \mathrm{C}$, and strong, cold winds predominantly from the southwest with a mean annual speed of up to $22 \mathrm{~km} \mathrm{~h}^{-1}$ and gusts that may exceed $100 \mathrm{~km} \mathrm{~h}^{-1}$. All samples were collected at $\sim 3.50 \mathrm{~m}$ above the Argentinean hydrographic zero.

Sample design

To investigate the macrofaunal assemblages associated with the three engineered habitats, $20 \times 20 \mathrm{~cm}$ samples were obtained seasonally from 2007 to 2009 and placed into the following three categories: (1) samples engineered by cordgrasses and mats of mussels covering their roots and rhizomes ( $n=30$, hereafter $\boldsymbol{S}$ - $\boldsymbol{M}$ ); (2) samples engineered by mussels ( $n=30$, hereafter $\boldsymbol{M}$ ) and (3) samples engineered by barnacles $(n=30$, hereafter $\boldsymbol{B})$. In the field, samples were carefully placed in plastic bags with ice. At the laboratory, the macrofauna of $\boldsymbol{S}$ - $\boldsymbol{M}$ samples was macroscopically sorted from above-ground and below-ground plant material, followed by a second sorting through a $0.5-\mathrm{mm}$ mesh. The rest of the samples $(\boldsymbol{M}$ and $\boldsymbol{B})$ were sorted through a sieve of $0.5-\mathrm{mm}$ mesh. The retained material was always fixed in $10 \%$ formalin for $48 \mathrm{~h}$ and then preserved in $70 \%$ ethanol. Organisms retained on the sieve (excluding mussels and barnacles when they formed the engineered habitats) were counted and identified to the lowest possible taxonomic level. A voucher of each specimen collected was deposited in the invertebrate collection of the CENPAT (www.cenpat.edu.ar).

Data analysis

Multivariate approaches were used to examine macroinvertebrates assemblages in each engineered habitat. These 

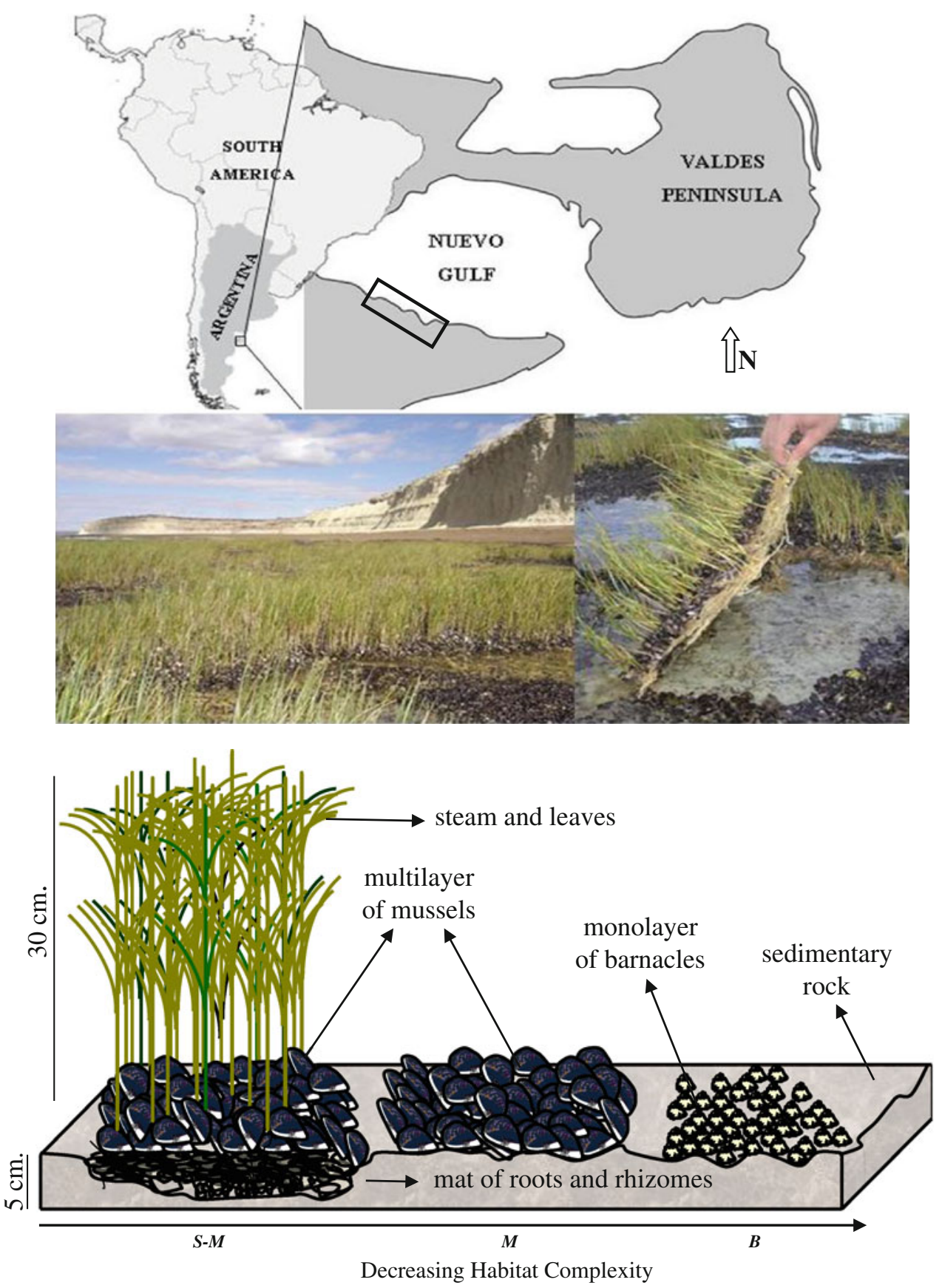

Fig. 1 Top: map showing the location of the study site. Center: landscape physiognomy of a typical Patagonian rocky salt marsh and close-up of the cordgrass-mussel-engineered habitat. Bottom: schematic representation of the studied ecosystem engineers inhabiting

analyses were carried out using Primer Statistical software (Clarke and Warwick 1994). The data matrix of all invertebrate species was 4th-root transformed in order to downweight the abundant species. Non-metric multidimensional scaling (MDS) was used to explore community similarities and differences for macroinvertebrates assemblages in the engineered habitats. Stress values $<0.1$ and $<0.2$ indicate good and useful resolutions, respectively, of the rocky salt marshes. Cordgrass-mussel-engineered habitat $(\boldsymbol{S}-\boldsymbol{M})$, mussel-engineered habitat $(\boldsymbol{M})$, and barnacle-engineered habitat (B) (Photograph credits: A. Bortolus)

two-dimensional MDS plot (Clarke and Warwick 1994). Pairwise comparisons for significant differences in macroinvertebrates assemblages between engineered habitats were made using a one-way analysis of similarity (ANOSIM), and a similarity percentage (SIMPER) analyses were used to determine the taxa responsible for the differences between groups. These analyses were based on Bray-Curtis similarity indexes. 
Table 2 Mean

density \pm standard deviation of invertebrate species (ind $100 \mathrm{~cm}^{-2}$ ) on data pooled over four sampling seasons
Cordgrass-mussel-engineered habitat $(\boldsymbol{S}-\boldsymbol{M})$, musselengineered habitat $(\boldsymbol{M})$, and barnacle-engineered habitat $(\boldsymbol{B})$

\begin{tabular}{|c|c|c|c|}
\hline & $S-M$ & $M$ & $\boldsymbol{B}$ \\
\hline \multicolumn{4}{|l|}{ Crustacea } \\
\hline Orchestia gammarella (Pallas) 1766 & $7 \pm 11$ & $0.2 \pm 0.7$ & $0.04 \pm 0.11$ \\
\hline Amphitoe valida Smith, 1873 & $0.01 \pm 0.06$ & 0 & $0.1 \pm 0.4$ \\
\hline Melita palmata (Montagu, 1804) & $0.1 \pm 0.5$ & $2 \pm 5$ & $0.1 \pm 0.8$ \\
\hline Monocorophium insidiosum (Crawford, 1937) & $0.2 \pm 0.3$ & $1 \pm 3$ & $2 \pm 5$ \\
\hline Tanais dulongii (Audouin, 1826) & $29 \pm 27$ & $44 \pm 27$ & $20 \pm 24$ \\
\hline Exosphaeroma sp. & $2 \pm 6$ & $2 \pm 4$ & $1 \pm 4$ \\
\hline Pseudosphaeroma sp. & $14 \pm 12$ & $6 \pm 10$ & $28 \pm 32$ \\
\hline Idotea $\mathrm{sp}$. & $0.01 \pm 0.03$ & 0 & 0 \\
\hline Cyrtograpsus altimanus Rathbun, 1914 & $2 \pm 2$ & $2 \pm 2$ & $0.3 \pm 0.9$ \\
\hline \multicolumn{4}{|l|}{ Polychaeta } \\
\hline Eulalia sp. & $1 \pm 1$ & $1 \pm 1$ & $0.4 \pm 0.5$ \\
\hline Boccardia polybranchia (Haswell, 1885) & $1 \pm 2$ & $9 \pm 16$ & $55 \pm 34$ \\
\hline Scoletoma tetraura $($ Schmarda, 1861$)$ & $0.04 \pm 0.10$ & 0 & 0 \\
\hline Syllidae & $0.3 \pm 0.6$ & $0.1 \pm 0.3$ & $1 \pm 1$ \\
\hline Capitellidae & $0.1 \pm 0.4$ & $1.6 \pm 2.5$ & 0 \\
\hline Orbiniidae & $0.8 \pm 1.4$ & $1.3 \pm 3.2$ & $0.2 \pm 0.5$ \\
\hline \multicolumn{4}{|l|}{ Bivalvia } \\
\hline Lasaea sp. & $0.2 \pm 0.4$ & $0.1 \pm 0.3$ & $1 \pm 2$ \\
\hline Mytilus sp. & $2 \pm 2$ & $1 \pm 1$ & $0.2 \pm 0.5$ \\
\hline \multicolumn{4}{|l|}{ Gastropoda } \\
\hline Siphonaria lessoni Blainville, 1824 & $6 \pm 4$ & $11 \pm 5$ & $14 \pm 6$ \\
\hline Trophon geversianus (Pallas 1769) & $0.01 \pm 0.02$ & 0 & 0 \\
\hline Nemertea & $2 \pm 3$ & $2 \pm 2$ & $1 \pm 2$ \\
\hline Actinaria & $4 \pm 5$ & $2 \pm 4$ & $0.01 \pm 0.04$ \\
\hline Ofiuroidea & $0.01 \pm 0.03$ & $0.01 \pm 0.03$ & 0 \\
\hline Total richness & 22 & 18 & 17 \\
\hline
\end{tabular}

In addition, species richness, diversity (Shannon's index $H$ ), and total density (ind $100 \mathrm{~cm}^{-2}$ ) were compared among engineered habitats within each season using ANOVA tests or the nonparametric Kruskal-Wallis test when variances were heterogeneous and could not be stabilized after different transformations. Significant results were analyzed a posteriori with the Scheffé test after the ANOVAs, or with multiple comparisons of mean ranks after Kruskal-Wallis test (Zar 1999).

\section{Results}

A total of 103,287 individuals of 22 species of benthic macroinvertebrates were found in the three engineered habitats in which the most common taxa were crustaceans and polychaetes (Table 2). The replication was originally planned to be balanced ( $n=30$ per category), however, due to non-planned logistic constrains the final replicate number involved in this description was 30 for $\boldsymbol{S}-\boldsymbol{M}, 20$ for $\boldsymbol{M}$, and 10 for $\boldsymbol{B}$. In order to prevent biased analysis and flawed interpretations, but also trying to avoid the unnecessary sacrifice of valid replicates, we randomly chose a balanced set of ten plots per category and compared them statistically. After repeating this procedure three times, with three different sets of 10 randomly chosen replicates we always found the results consistent and never different from the unbalanced analysis (i.e. including $n=30,20$ and 10). The dominant species found showed a differential distribution among engineered habitats: the cryptogenic Tanais dulongii was more abundant at $\boldsymbol{M}$ habitat (Kruskal-Wallis test: $H=30.84, P<0.01$, post hoc test, $\boldsymbol{M}>\boldsymbol{S}-\boldsymbol{M}=\boldsymbol{B}, P<0.01)$, the isopod Pseudosphaeroma sp. at $\boldsymbol{B}$ habitat (Kruskal-Wallis test: $H=51.18$, $P<0.01$, post hoc test: $\boldsymbol{B}>\boldsymbol{S}-\boldsymbol{M}=\boldsymbol{M}, P<0.01$ ), and the limpet Siphonaria lessoni at $\boldsymbol{M}$ and $\boldsymbol{B}$ habitats (KruskalWallis test: $H=75.96, P<0.01$, post hoc test, $\boldsymbol{M}=\boldsymbol{B}>$ $\boldsymbol{S}$ - $\boldsymbol{M}, \boldsymbol{P}<0.01)$. Of the total taxa identified, $70 \%$ were common to the three engineered habitats and just the isopod Idotea sp., the gastropod Trophon geversianus, and the polychaete Scoletoma tetraura, were exclusively found in habitat from $\boldsymbol{S}-\boldsymbol{M}$ but at very low density $(\leq 0.01$ ind $100 \mathrm{~cm}^{-2}$, Table 2). However, the amphipod Orchestia gammarella was found almost exclusively at high density 


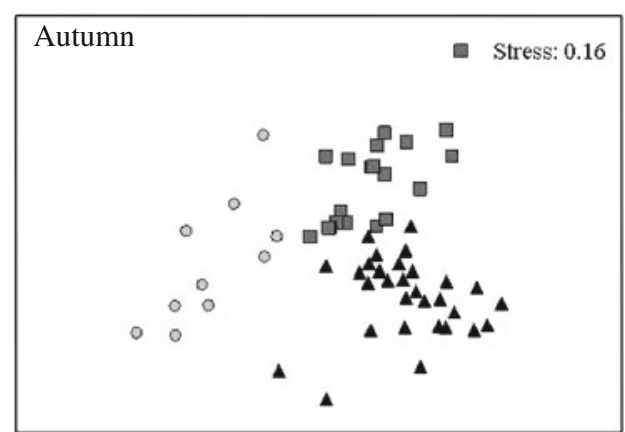

$\boldsymbol{S}$ - $\boldsymbol{M}$ vs. $\boldsymbol{M}$ : $\mathrm{R}=0.5, \mathrm{p}=0.01 ; \boldsymbol{S}$ - $\boldsymbol{M}$ vs. $\boldsymbol{B}: \mathrm{R}=0.9, \mathrm{p}=0.01$; M vs. $B: \mathrm{R}=0.7, \mathrm{p}=0.01$

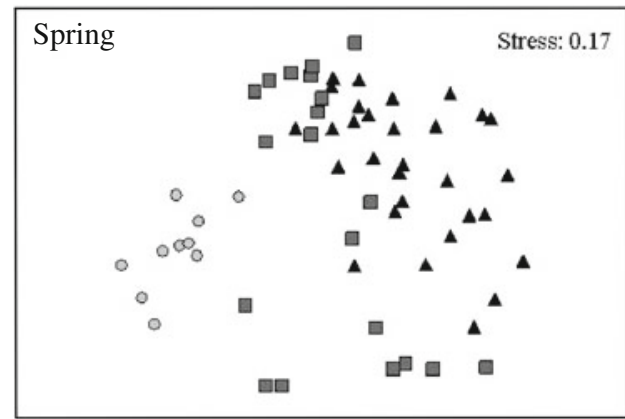

$\boldsymbol{S}$ - $\boldsymbol{M}$ vs. $\boldsymbol{M}: \mathrm{R}=0.3, \mathrm{p}=0.01 ; \boldsymbol{S}-\boldsymbol{M}$ vs. $\boldsymbol{B}: \mathrm{R}=0.9, \mathrm{p}=0.01 ;$

Mvs. $B: \mathrm{R}=0.4, \mathrm{p}=0.01$

Fig. 2 Two-dimensional MDS ordination comparing macroinvertebrates densities associated with cordgrass-mussel-engineered habitat and results of pairwise comparisons using ANOSIM test at each season. Cordgrass-mussel-engineered habitat: black triangles;

in $\boldsymbol{S}$ - $\boldsymbol{M}$ habitats (Kruskal-Wallis test; $H=71.88, P<0.01$, post hoc test, $\boldsymbol{S}-\boldsymbol{M}>\boldsymbol{M}=\boldsymbol{B}, P<0.01$, Table 2).

The MDS plots jointly with the ANOSIM procedure showed that macroinvertebrates assemblages in $\boldsymbol{B}$ clearly separated from $\boldsymbol{S}-\boldsymbol{M}$ and $\boldsymbol{M}$ in all seasons while $\boldsymbol{S}-\boldsymbol{M}$ and $\boldsymbol{M}$ showed a certain degree of overlapping (Fig. 2). Since most of the taxa were shared by the three engineered habitats, these results were mainly due to differences in individual densities. The most discriminating taxa among engineered habitats along all the seasons were the polychaete Boccardia polybranchia and the crustaceans Orchestia gammarella, Pseudosphaeroma sp. and Tanais dulongii (Table 3). Large abundances of B. polybranchia and Pseudosphaeroma sp. were characteristic of $\boldsymbol{B}$ habitats while higher densities of $O$. gammarella and $T$. dulongii were characteristic of $\boldsymbol{S}-\boldsymbol{M}$ and $\boldsymbol{M}$, respectively (Table 3). The mussel Mytilus sp., the sea anemones, and the nemerteans also accounted for differences among engineered habitats, but to a lesser extent (Table 3).

Species richness, diversity, and total density differed significantly among the engineered habitats (Table 4). $\boldsymbol{S}-\boldsymbol{M}$ and $\boldsymbol{M}$ habitats were more species rich and diverse than $\boldsymbol{B}$ (Table 4). This greater richness showed by $\boldsymbol{S}-\boldsymbol{M}$ and

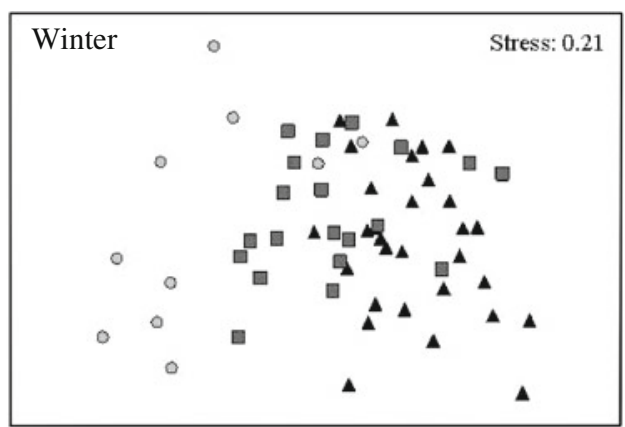

$S$ - $\boldsymbol{M}$ vs. $\boldsymbol{M}: \mathrm{R}=0.2, \mathrm{p}=0.01 ; \boldsymbol{S}-\boldsymbol{M}$ vs. $\boldsymbol{B}: \mathrm{R}=0.7, \mathrm{p}=0.01$ M vs. B: $\mathrm{R}=0.5, \mathrm{p}=0.01$

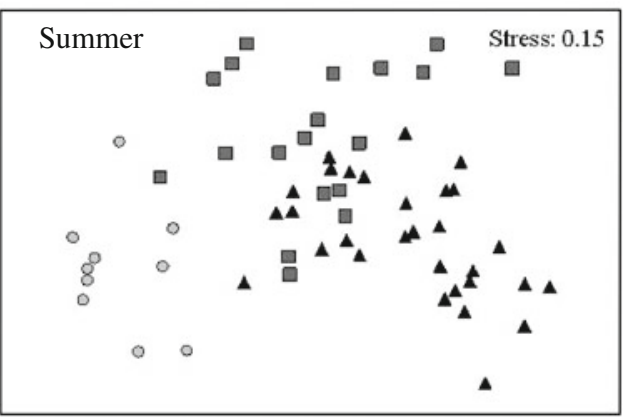

$S$ - $\boldsymbol{M}$ vs. $\boldsymbol{M}: \mathrm{R}=0.3, \mathrm{p}=0.01 ; \boldsymbol{S}-\boldsymbol{M}$ vs. $\boldsymbol{B}: \mathrm{R}=0.9, \mathrm{p}=0.01 ;$

M vs. $B: \mathrm{R}=0.7, \mathrm{p}=0.01$

mussel-engineered habitat: dark gray squares; barnacle-engineered habitat: gray circles. Data were 4th-root transformed in order to down-weight abundant species

$M$ resulted from the presence of some rare species in these habitats. On the other hand, $\boldsymbol{B}$ showed significantly higher total densities over all seasons (Table 4), which was mainly drive by the high density of the worm Boccardia polybranchia.

\section{Discussion}

As we expected, the macroinvertebrate assemblages we studied showed a variable species relative distribution and abundance in presence of different ecosystem engineers. Although we found similar suites of species, the relative density of many individual species was markedly different among contrasting engineered habitats. Moreover, while species richness and diversity increased jointly with the habitat complexity provided by the ecosystem engineers, the total density showed the opposite trend.

The $\boldsymbol{S}$ - $\boldsymbol{M}$-engineered habitat was characterized by the exclusive presence of the gammaridean amphipod Orchestia gammarella, a likely introduced species (Orensanz et al. 2002) that was virtually absent from $\boldsymbol{M}$ and $\boldsymbol{B}$. Other related species of amphipod have been reported as a characteristic component of salt marsh communities 
Table 3 Results of the SIMPER routine showing the species, which made the greatest contributions to dissimilarity in significant contrast between engineered habitats at each season ranked by decreasing power $(\%)$

\begin{tabular}{|c|c|c|c|c|c|}
\hline & Taxa & Av. density & Av. density & Contrib. \% & Cum. \% \\
\hline & & $S-M$ & $M$ & & \\
\hline Autumn & Pseudosphaeroma sp. & 37.30 & 6.80 & 14.87 & 14.87 \\
\hline Groups $\boldsymbol{S}-\boldsymbol{M} \& \boldsymbol{M}$ & Orchestia gammarella & 8.00 & 0.00 & 13.44 & 28.31 \\
\hline \multirow[t]{3}{*}{ Av. dissimilarity $=31.99$} & Boccardia polybranchia & 1.00 & 23.35 & 12.63 & 40.94 \\
\hline & Mytilus sp. & 3.78 & 2.28 & 9.31 & 50.25 \\
\hline & & $S-M$ & $\boldsymbol{B}$ & & \\
\hline Groups $S-M \& B$ & Boccardia polybranchia & 0.25 & 53.38 & 24.71 & 24.71 \\
\hline \multirow[t]{4}{*}{ Av. dissimilarity $=43.81$} & Cyrtograpsus altimanus & 3.61 & 0.10 & 10.88 & 35.59 \\
\hline & Orchestia gammarella & 7.24 & 0.00 & 10.83 & 46.43 \\
\hline & Mytilus sp. & 2.33 & 0.18 & 8.66 & 55.09 \\
\hline & & $M$ & $\boldsymbol{B}$ & & \\
\hline Groups $\boldsymbol{M} \& \boldsymbol{B}$ & Boccardia polybranchia & 5.84 & 53.38 & 17.13 & 17.13 \\
\hline \multirow[t]{4}{*}{ Av. dissimilarity $=40.86$} & Pseudosphaeroma sp. & 1.70 & 15.60 & 13.95 & 31.08 \\
\hline & Cyrtograpsus altimanus & 4.19 & 0.10 & 12.34 & 43.42 \\
\hline & Nemertea & 2.81 & 0.18 & 10.12 & 53.55 \\
\hline & & $S-M$ & $M$ & & \\
\hline Winter & Actinaria & 5.08 & 2.46 & 12.71 & 12.71 \\
\hline Groups $\boldsymbol{S}-\boldsymbol{M} \& \boldsymbol{M}$ & Boccardia polybranchia & 1.11 & 7.10 & 11.92 & 24.63 \\
\hline \multirow[t]{4}{*}{ Av. dissimilarity $=25.76$} & Orchestia gammarella & 2.45 & 0.33 & 10.38 & 35.01 \\
\hline & Pseudosphaeroma sp. & 11.36 & 7.86 & 9.62 & 44.63 \\
\hline & Mytilus sp. & 2.39 & 0.95 & 8.96 & 53.59 \\
\hline & & $S-M$ & $\boldsymbol{B}$ & & \\
\hline Groups $\boldsymbol{S}-\boldsymbol{M} \& \boldsymbol{B}$ & Boccardia polybranchia & 1.11 & 39.00 & 17.02 & 17.02 \\
\hline \multirow[t]{5}{*}{ Av. dissimilarity $=36.44$} & Actinaria & 5.08 & 0.03 & 11.36 & 28.38 \\
\hline & Pseudosphaeroma sp. & 11.36 & 48.18 & 9.97 & 38.35 \\
\hline & Tanais dulongii & 45.36 & 38.73 & 9.19 & 47.54 \\
\hline & Monocorophium insidiosum & 0.32 & 4.85 & 8.82 & 56.36 \\
\hline & & $M$ & $\boldsymbol{B}$ & & \\
\hline Groups $\boldsymbol{M} \& \boldsymbol{B}$ & Pseudosphaeroma sp. & 7.86 & 48.18 & 14.36 & 14.36 \\
\hline \multirow[t]{5}{*}{ Av. dissimilarity $=31.21$} & Boccardia polybranchia & 7.10 & 39.00 & 13.78 & 28.13 \\
\hline & Tanais dulongii & 58.93 & 38.73 & 10.62 & 38.76 \\
\hline & Monocorophium insidiosum & 0.69 & 4.85 & 10.39 & 49.15 \\
\hline & Actinaria & 2.46 & 0.03 & 9.37 & 58.52 \\
\hline & & $S-M$ & $M$ & & \\
\hline Spring & Pseudosphaeroma sp. & 19.01 & 10.61 & 14.13 & 14.13 \\
\hline Groups $\boldsymbol{S}-\boldsymbol{M} \& \boldsymbol{M}$ & Orchestia gammarella & 6.88 & 0.13 & 12.26 & 26.69 \\
\hline \multirow[t]{4}{*}{ Av. dissimilarity $=33.84$} & Actinaria & 4.30 & 2.61 & 11.48 & 38.17 \\
\hline & Boccardia polybranchia & 1.17 & 7.46 & 10.58 & 48.76 \\
\hline & Tanais dulongii & 27.27 & 40.55 & 9.91 & 58.67 \\
\hline & & $S-M$ & $\boldsymbol{B}$ & & \\
\hline Groups $\boldsymbol{S}-\boldsymbol{M} \& \boldsymbol{B}$ & Boccardia polybranchia & 1.17 & 76.03 & 24.20 & 24.20 \\
\hline \multirow[t]{4}{*}{ Av. dissimilarity $=43.79$} & Actinaria & 4.30 & 0.00 & 11.34 & 35.54 \\
\hline & Orchestia gammarella & 6.88 & 0.05 & 10.70 & 46.23 \\
\hline & Mytilus sp. & 1.40 & 0.00 & 10.59 & 56.83 \\
\hline & & $M$ & $\boldsymbol{B}$ & & \\
\hline Groups $\boldsymbol{M} \& \boldsymbol{B}$ & Boccardia polybranchia & 7.46 & 76.03 & 24.12 & 24.12 \\
\hline \multirow[t]{3}{*}{ Av. dissimilarity $=40.05$} & Pseudosphaeroma sp. & 10.61 & 13.25 & 12.27 & 36.38 \\
\hline & Tanais dulongii & 40.55 & 12.53 & 9.65 & 46.03 \\
\hline & Nemertea & 2.11 & 0.10 & 9.38 & 55.38 \\
\hline
\end{tabular}


Table 3 continued

\begin{tabular}{|c|c|c|c|c|c|}
\hline & Taxa & Av. density & Av. density & Contrib. $\%$ & Cum. $\%$ \\
\hline & & $S-M$ & $M$ & & \\
\hline Summer & Orchestia gammarella & 9.56 & 0.42 & 13.93 & 13.93 \\
\hline Groups $\boldsymbol{S}-\boldsymbol{M} \& \boldsymbol{M}$ & Boccardia polybranchia & 1.51 & 14.92 & 13.58 & 27.52 \\
\hline \multirow[t]{3}{*}{ Av. dissimilarity $=31.96$} & Pseudosphaeroma sp. & 17.82 & 4.99 & 13.26 & 40.77 \\
\hline & Tanais dulongii & 25.75 & 37.86 & 10.37 & 51.14 \\
\hline & & $S-M$ & $\boldsymbol{B}$ & & \\
\hline Groups $S-M \& B$ & Boccardia polybranchia & 1.51 & 50.95 & 20.30 & 20.30 \\
\hline \multirow[t]{4}{*}{ Av. dissimilarity $=45.59$} & Actinaria & 3.51 & 0.00 & 12.30 & 32.60 \\
\hline & Orchestia gammarella & 9.56 & 0.05 & 11.57 & 44.16 \\
\hline & Mytilus sp. & 2.10 & 0.00 & 10.91 & 55.07 \\
\hline & & $M$ & $\boldsymbol{B}$ & & \\
\hline Groups $\boldsymbol{M} \& \boldsymbol{B}$ & Pseudosphaeroma sp. & 4.99 & 35.60 & 15.61 & 15.61 \\
\hline \multirow[t]{3}{*}{ Av. dissimilarity $=40.71$} & Boccardia polybranchia & 14.92 & 50.95 & 14.95 & 30.56 \\
\hline & Nemertea & 3.00 & 0.08 & 11.12 & 41.68 \\
\hline & Actinaria & 1.80 & 0.00 & 9.16 & 51.49 \\
\hline
\end{tabular}

Lists were truncated whenever cumulative percentage reached 50\%. Cordgrass-mussel-engineered habitat $(\boldsymbol{S}$ - $\boldsymbol{M})$, mussel-engineered habitat $(\boldsymbol{M})$, and barnacle-engineered habitat $(\boldsymbol{B})$

Table 4 Results of the ANOVA and the Scheffé tests comparing community parameters among the three ecosystems engineered habitats (EE) at each season

\begin{tabular}{|c|c|c|c|c|c|c|c|c|c|c|}
\hline \multirow[t]{2}{*}{ Seasons } & \multirow[t]{2}{*}{ Factor } & \multicolumn{3}{|c|}{ Diversity } & \multicolumn{3}{|c|}{ Species richness } & \multicolumn{3}{|c|}{ Total density } \\
\hline & & $\mathrm{F}_{2,57}$ & $P$ & Scheffé test & $F_{2,57}$ & $P$ & Scheffé test & $\mathrm{F}_{2,57}$ & $P$ & Scheffé test \\
\hline Autumn & $\mathrm{EE}$ & 9.70 & $<0.01$ & $B<M=S-M$ & 1.83 & 0.17 & & 14.90 & $<0.01$ & $B>M=S-M$ \\
\hline Winter & $\mathrm{EE}$ & 0.68 & 0.51 & & 8.98 & $<0.01$ & $B<M=S-M$ & 60.80 & $<0.01$ & $B>M=S-M$ \\
\hline Spring & $\mathrm{EE}$ & 14.01 & $<0.01$ & $B<M=S-M$ & 11.22 & $<0.01$ & $B=M<S-M$ & 11.50 & $<0.01$ & $B>M=S-M$ \\
\hline Summer & $\mathrm{EE}$ & 12.54 & $<0.01$ & $B<M=S-M$ & 20.09 & $<0.01$ & $B<M=S-M$ & 9.00 & $<0.01$ & $B>M=S-M$ \\
\hline
\end{tabular}

Cordgrass-mussel-engineered habitat $(\boldsymbol{S}-\boldsymbol{M})$, mussel-engineered habitat $(\boldsymbol{M})$, and barnacle-engineered habitat $(\boldsymbol{B})$

(Laffaille et al. 2001; Agnew et al. 2003; Idaszkin 2006; Cattrijsse and Hampel 2006; Bortolus et al. 2009). The absence of this amphipod at $\boldsymbol{M}$ and $\boldsymbol{B}$ habitats and its strong association with $\boldsymbol{S}$ - $\boldsymbol{M}$ seem linked to the shelter and food provided by plants, which supports the hypothesis that the austral cordgrass Spartina densiflora supplies a particular habitat that resulted in the net addition of new species to the invertebrate community commonly characterizing the local rocky shores (Adami et al. 2004). This addition implies an important ecological event since $O$. gammarella amphipods are able to modulate ecosystem variables such as primary production by feeding on plant detritus (Agnew et al. 2003; Dias and Hassall 2005). These crustaceans are even capable of acting as important links between semi-terrestrial and marine ecosystems since they have been reported to be an important food source for coastal fishes (Laffaille et al. 2001; Ludlam et al. 2002; Cattrijsse and Hampel 2006) and nemerteans (McDermott and Roe 1985).

The habitat created by the non-native barnacle Balanus glandula showed the highest density of the tubiculous spionid worm Boccardia polybranchia, a common cryptogenetic species in the intertidal zone of the area. The Spionidae is one of the most abundant families of Polychaeta, and it is able to inhabit any kind of substratum in shallow waters (Fauchald and Jumars 1979). We found this polychaete within burrows or in tubes made of mud and detritus in the crevices in-between barnacles where it probably finds protection from predation and/or from harsh environmental conditions such as heat stress, dehydration, and the impact of waves.

Among the three engineered habitats we studied, the species richness and diversity were significantly higher in those more complex. Our results support the hypothesis that greater amounts of structure and physical dimensions increase the availability of surface and therefore greater resources, which in turn increase the number of possible niches to exploit. It seems unlikely, however, that the relationship between complexity and diversity is linear. The highest values of total density were found associated with the least complex habitat-the barnacles-contrary 
to that general pattern. Some of the authors in Table 1 hypothesized that extremely complex habitats could actually exclude organisms, which implies that the maximal density would be in some intermediate level of habitat complexity. The fact that we did not find a difference in species richness, diversity, and total density between the most complex $(\boldsymbol{S}-\boldsymbol{M})$ and the intermediate $(\boldsymbol{M})$ habitats suggest the need to consider either a greater spectrum of possibilities or a stronger contrast in complexity among the habitats considered in order to have a more complete picture of the problem. Several studies have reported the occurrence of similar species composition in similar habitats (Table 1), and a parsimonious hypotheses explaining this pattern refers to the potential redundancy in habitat provision by the engineers, since many of the engineers can accomplish the same essential ecological role (Kelaher et al. 2007). This can also be seen in our results where the pool of species found associated with $\boldsymbol{S}-\boldsymbol{M}$ and $\boldsymbol{M}$ overlapped greatly. The neutral relationship we found between these two habitats indicates that, once a certain level of complexity is reached, additional complexity would not significantly alter the richness, diversity, and/or total density of the associated species.

In summary, our study strongly suggests that the species vary their relative distribution and abundances in presence of the different habitats complexities generated by $\boldsymbol{S}-\boldsymbol{M}, \boldsymbol{M}$, and $\boldsymbol{B}$. However, the direction (i.e., neutral, positive or negative) and intensity of the community response to the ecosystem engineer organisms may be conditioned by the physiological requirements of the different species and their efficiency to readjust their local spatial distribution in the short term.

Acknowledgments We are grateful to G. Alonso (MACN), B. Doti and D. Roccatagliata (UBA) and to E. Diez (CENPAT) for assisting us with the taxonomic identification of amphipods, tanaids, isopods and polychaetes, respectively. We thank Y. Idaszkin for helping us with the field work and A. Pickart for her invaluable willingness to review the text in order to improve the English. The constructive comments and suggestions made by two reviewers and the editors are greatly appreciated. CONICET, ANPCyT-FONCyT (PICT No 14666 and 2206 to $\mathrm{AB}$ and PICT No 20621 to ES) and GEF (PNUD ARG 02/018 A-B17, to AB) supplied financial support. This work is part of the doctoral Thesis of the first author at Universidad de Buenos Aires (UBA), Argentina.

\section{References}

Adami ML, Tablado A, López Gappa J (2004) Spatial and temporal variability in intertidal assemblages dominated by the mussel Brachidontes rodriguezii (d'Orbigny, 1846). Hydrobiologia 520:49-59

Agnew AM, Shull DH, Buschbaum R (2003) Growth of a salt marsh invertebrate on several species of marsh grass detritus. Biol Bull 205:238-239
Angradi TR, Hagan SM, Able KW (2001) Vegetation type and the intertidal macroinvertebrate fauna of a brackish marsh: Phragmites vs. Spartina. Wetlands 21:75-92

Barnes M (2000) The use of intertidal barnacle shells. Oceanogr Mar Biol Ann Rev 38:157-187

Bertness MD, Crain CM, Silliman BR, Bazterrica MC, Reyna MV, Hidalgo F, Farina JK (2006) The community structure of Western Atlantic Patagonian rocky shores. Ecol Monogr 76:439-460

Borthagaray AI, Carranza A (2007) Mussels as ecosystem engineers: their contribution to species richness in rocky littoral community. Acta Oecol 31:243-250

Bortolus A (2006) The austral cordgrass Spartina densiflora Brong: its taxonomy, biogeography and natural history. J Biogeogr 33:158-168

Bortolus A, Schwindt E, Iribarne O (2002) Positive plant-animal interaction in the high marsh of an Argentinean coastal lagoon. Ecology 83:733-742

Bortolus A, Schwindt E, Bouza PJ, Idaszkin YL (2009) A characterization of Patagonian salt marsh. Wetlands 29:772-780

Bouma TJ, Olenin S, Reise K, Ysebaert T (2009) Ecosystem engineering and biodiversity in coastal sediments: posing hypotheses. Helgol Mar Res 63:95-106

Bros WE (1980) Effects of removing or adding structure (barnacle shells) on recruitment to a fouling community in Tampa Bay, Florida. J Exp Mar Biol Ecol 105:275-296

Brusati ED, Grosholz ED (2006) Native and introduced ecosystem engineers produce contrasting effects on estuarine infaunal communities. Biol Invasions 8:683-695

Buschbaum C, Dittmann S, Hong JS, Hwang IS, Strasser M, Thiel M, Valdivia N, Yoon SP, Reise K (2009) Mytilid mussels: global habitat engineers in coastal sediments. Helgol Mar Res 63:47-58

Callaway R (2006) Tube worms promote community change. Mar Ecol Prog Ser 308:49-60

Capehart AA, Hackney C (1989) The potential role of roots and rhizomes in structuring salt marsh benthic communities. Estuaries 12:119-122

Castilla JC, Lagos NA, Cerda M (2004) Marine ecosystem engineering by the alien ascidian Pyura praeputialis on a mid-intertidal rocky shore. Mar Ecol Prog Ser 268:119-130

Cattrijsse A, Hampel H (2006) European intertidal marshes: a review of their habitat functioning and value of aquatic organisms. Mar Ecol Prog Ser 324:293-307

Chapman MG, People J, Blockley D (2005) Intertidal assemblages associated with natural coralline turf and invasive mussel beds. Biodivers Conserv 14:1761-1776

Chemello R, Milazzo M (2002) Effect of algal architecture on associated fauna: some evidence from phytal mollusks. Mar Biol 140:981-990

Christie H, Jørgensen NM, Norderhaug KN (2007) Bushy or smooth, high or low; importance of habitat architecture and vertical position for distribution of fauna on kelp. J Sea Res 58:98-208

Clarke KR, Warwick RM (1994) Change in marine communities: an approach to statistical analysis and interpretation. Natural Environment Research Council, Plymouth

Commito JA, Como C, Grupe BM, Dowa WE (2008) Species diversity in the soft-bottom intertidal zone: biogenic structure, sediment, and macrofauna across mussel bed spatial scales. J Exp Mar Biol Ecol 366:70-81

Connor EF, McCoy ED (2001) Species-area relationships. In: Levin S (ed) Encyclopedia of Biodiversity. Acad. Press, London, pp 397-411

Cottet M, de Montaudouin X, Blanchet H, Lebleu P (2007) Spartina anglica eradication experiment and in situ monitoring assess structuring strength of habitat complexity on marine macrofauna at high tidal level. Estuar Coast Shelf Sci 71:629-640 
Crooks JA (2002) Characterizing ecosystem-level consequences of biological invasions: the role of ecosystem engineers. Oikos 97:153-166

Dias N, Hassall M (2005) Food, feeding and growth rates of peracarid macro-decomposers in a Ria Formosa salt marsh, southern Portugal. J Exp Mar Biol Ecol 325:84-94

Edgar GJ, Klumpp DW (2003) Consistencies over regional scales in assemblages of mobile epifauna associated with natural and artificial plants of different shape. Aquat Bot 75:275-291

Fauchald C, Jumars PA (1979) The diet of worms: a study of Polychaete feeding guilds. Oceanogr Mar Biol Ann Rev 17:193-284

Fortuné PM, Schierenbeck K, Ayres D, Bortolus A, Catrice O, Brown S, Ainouche M (2008) The enigmatic invasive Spartina densiflora: a history of hybridizations in a polyploidy context. Mol Ecol 17:4304-4316

Gutiérrez JL, Iribarne OO (2004) Conditional responses of organisms to habitat structure: an example from intertidal mudflats. Oecologia 139:572-582

Harley CDG (2006) Effects of physical ecosystem engineering and herbivory on intertidal community structure. Mar Ecol Prog Ser 317:29-39

Hastings A, James E, Byers J, Crooks A, Cuddington K, Jones CG, Lambrinos JG, Talley TS, Wilson WG (2007) Ecosystem engineering in space and time. Ecol Lett 10:153-164

Hedge P, Kriwokwen LK (2000) Evidence for effects of Spartina anglica invasion on benthic macrofauna in little swanport estuary, Tasmania. Aust Ecol 25:150-159

Heiman KW, Vidargas N, Micheli F (2008) Non-native habitat as home for non-native species: comparison of communities associated with invasive tubeworm and native oyster reefs. Aquat Biol 2:47-56

Hooper GJ, Davenport J (2006) Epifaunal composition and fractal dimensions of intertidal marine macroalgae in relation to emersion. J Mar Biol Ass UK 86:1297-1304

Hull SL (1997) Seasonal changes in diversity and abundance of ostracods on four species of intertidal algae with differing structural complexity. Mar Ecol Prog Ser 161:71-82

Idaszkin YL (2006) Relaciones entre la dominancia botánica y la riqueza específica, abundancia y distribución espacial de macroinvertebrados marinos en marismas de Península Valdés, Chubut. Licenciatura Thesis, Universidad Nacional de la Patagonia San Juan Bosco, Argentina

Jackson AC, Chapman MG, Underwood AJ (2008) Ecological interactions in the provision of habitat by urban development: whelks and engineering by oysters on artificial seawalls. Aust Ecol 33:307-316

Jones CG, Lawton JH, Shachak M (1994) Organisms as ecosystem engineers. Oikos 69:373-386

Jones CG, Lawton JH, Shachak M (1997) Positive and negative effects of organisms as physical ecosystem engineers. Ecology 78:1946-1957

Kelaher BP (2003) Changes in habitat complexity negatively affect diverse gastropod assemblages in coralline algal turf. Oecologia 135:431-441

Kelaher BP, Castilla JC, Prado L (2007) Is there redundancy in bioengineering for molluscan assemblages on the rocky shores of central Chile? Rev Chil Hist Nat 80:173-186

Kochmann J, Buschbaum C, Volkenborn N, Reise K (2008) Shift from native mussels to alien oysters: differential effects of ecosystem engineers. J Exp Mar Biol Ecol 364:1-10

Laffaille P, Lefeuvre JC, Schricke MT, Feunteun E (2001) Feeding ecology of o-group sea bass, Dicentrarchus labrax, in salt marsh of Mont Michel Bay (France). Estuaries 24:116-125

Levin LA, Neira C, Grosholz E (2006) Invasive cordgrass modifies wetland trophic function. Ecology 87:419-432

Lewis FG (1984) Distribution of macrobenthic crustaceans associated with Thalassia, Halodule and bare sand substrata. Mar Ecol Prog Ser 19:101-113
Ludlam JP, Shull DH, Buschbaum R (2002) Effects of haying on salt marsh surface invertebrates. Biol Bull 203:250-251

Maggi E, Bertocci I, Vaselli S, Benedetti-Cecchi L (2009) Effects of changes in number, identity and abundance of habitat-forming species on assemblages of rocky seashores. Mar Ecol Prog Ser 381:39-49

McCoy ED, Bell SS (1991) Habitat structure: the evolution and diversification of a complex topic. In: Bell SS, McCoy ED, Mushinsky HR (eds) Habitat structure: the physical arrangement of objects in space. Chapman and Hall, New York, pp 3-27

McDermott JC, Roe P (1985) Food, feeding behavior and feeding ecology of Nemerteans. Am Zool 25:113-125

McKinnon GJ, Gribben PE, Davis AR, Jolley DF, Wright JT (2009) Differences in soft-sediment macrobenthic assemblages invaded by Caulerpa taxifolia compared to uninvaded habitats. Mar Ecol Prog Ser 380:59-71

Netto SA, Lana PL (1999) The role of above- and below-ground components of Spartina alterniflora (Loisel) and detritus biomass in structuring macrobenthic associations of Paranguá Bay (SE, Brazil). Hydrobiologia 400:167-177

Orensanz JL, Schwindt E, Pastorino G, Bortolus A, Casas G, Darrigran G, Elías R, López Gappa JJ, Obenat S, Pascual M, Penchaszadeh P, Piriz ML, Scarabino F, Spivak ED, Vallarino EA (2002) No longer the pristine confines of the world ocean: a survey of exotic marine species in the southwestern Atlantic. Biol Invasions 4:115-143

Prado L, Castilla JC (2006) The bioengineer Perumytilus purpuratus (Mollusca: Bivalvia) in central Chile: biodiversity, habitat structural complexity and environmental heterogeneity. J Mar Biol Ass UK 86:417-421

Raffo MP, Eyras MC, Iribarne OO (2009) The invasion of Undaria pinnatifida to a Macrocystis pyrifera kelp in Patagonia (Argentina, south-west Atlantic). J Mar Biol Ass UK 89:1571-1580

Savoya V, Schwindt E (2010) Effect of the substratum in the recruitment and survival of the introduced barnacle Balanus glandula (Darwin 1854) in Patagonia, Argentina. J Exp Mar Biol Ecol 382:125-130

Schmidt AL, Scheibling RE (2006) A comparison of epifauna and epiphytes on native kelps (Laminaria species) and an invasive alga (Codium fragile spp. tomentosoides) in Nova Scotia, Canada. Bot Mar 49:315-330

Schreider MJ, Glasby TN, Underwood AJ (2003) Effects of height on the shore and complexity of habitat on abundances of amphipods on rocky shores in New South Wales, Australia. J Exp Mar Biol Ecol 293:57-71

Schwindt E (2007) The invasion of the acorn barnacle Balanus glandula in the south-western Atlantic 40 years later. J Mar Biol Ass UK 87:1219-1225

Schwindt E, Bortolus A, Iribarne OO (2001) Invasion of a reefbuilder polychaete: direct and indirect impacts on the native benthic community structure. Biol Invasions 3:137-149

Sellheim K, Stachowicz JJ, Coates RC (2010) Effects of a nonnative habitat-forming species on mobile and sessile epifaunal communities. Mar Ecol Prog Ser 398:69-80

Thiel M, Ullrich N (2002) Hard rock versus soft bottom: the fauna associated with intertidal mussel beds on hard bottoms along the coast of Chile, and considerations on the functional role of mussel beds. Helgol Mar Res 56:21-30

Thomaz SM, Dibble ED, Evangelista LR, Higuti J, Bini LM (2008) Influence of aquatic macrophyte habitat complexity on invertebrate abundance and richness in tropical lagoons. Fresh Biol 53:358-367

Thompson RC, Wilson BJ, Tobin ML, Hill AS, Hawkins SJ (1996) Biologically generated habitat provision and diversity of rocky shore organisms at a hierarchy of spatial scales. J Exp Mar Biol Ecol 202:73-84

Zar JH (1999) Biostatistical analysis. Prentice Hall, New Jersey 